\title{
Shooting Down Military Aircraft: Pakistan Responsibilities Over India
}

Dewa Gede Sudika Mangku¹, Jilal Aqli²

\author{
1 Faculty of Law and Social Scences, Universitas Pendidikan Ganesha, Indonesia \\ dewamangku.undiksha@gmail.com \\ 2 Faculty of Law and Social Scences, Universitas Pendidikan Ganesha, Indonesia \\ jilalaqli@gmail.com
}

\begin{abstract}
Introduction to The Problem: The act of firing on two Indian military aircraft carried out by Pakistan indeed constitutes the right of air control over military aircraft according to the Paris Convention of 1919 and the Chicago Convention of 1944, according to which this convention's control rights over foreign military aircraft are strict and maximum, it does not contain exceptions Article 32 of the Paris Convention and Article 3 (c) of the 1944 Chicago Convention The right of maximum and strict control of the state over its airspace is only directed to military aircraft of other countries, where the consideration of national security is the main reason. But still, the shooting action carried out by Pakistan against Indian military aircraft is an act of negligence on airspace, which became its sovereignty, due to the lack of coordination related to the shootings carried out.

Purpose/Objective Study: This study aims to determine and understand the regulation of Indian military aircraft in the 1944 Chicago Convention on Flight of Military Aircraft to Airspace in Other Countries and the responsibility of the state of Pakistan in firing the Indian military plane from the perspective of international air law.

Design/Methodology/Approach: This research uses normative legal research methods using a type of legislation approach and case approach. The legal materials used are primary, secondary, and tertiary legal materials that are useful for obtaining conclusions relevant to the problems in this study.

Findings: The results showed that: 1) the regulation of Indian military aircraft in the 1944 Chicago Convention was categorized as a military aircraft (state aircraft) type of MiG-21 Bison interceptor, which was indeed used for military, police, and customs purposes, which in this case did not have the right to do flight above the airspace of another country before obtaining permission in advance from the country concerned; 2) the form of responsibility that must be given is in the way of termination of acts, apologies and remedial actions in the form of restitution, i.e., repairing as, before the Indian military aircraft that he shot and providing protection for pilots he captures, this is as regulated in Article 31 of the ILC Draft.
\end{abstract}

Paper Type: Research Article 
Keywords: State Responsibilities; Military Aircraft; Pakistan; India

\section{Introduction}

International law is a rule that contains the principles of law in which regulate relations that can cross national borders (Koh, 1998). In international law is known as international relations. International relations are usually carried out by legal subjects in international law, whether carried out between countries, countries with individuals, or countries with other international organizations. The relationship is not always going well. Sometimes these relationships cause various disputes. These disputes can originate from multiple sources of disputes. One of the dispute origins that can trigger conflicts between countries is air disputes, which in this case, are usually related to flights, especially violations of airspace sovereignty (Williams, 2010).

Air law regulates a country's sovereignty, especially in the airspace. The airspace of a country in the air law is divided into several regions, namely air space in the mainland area, inland sea area, territorial sea, and the territorial sea area of an island nation (Saul, 2013). The sovereignty of a country in the air space above its territorial territory is intact and full. It is regulated in Article 1 of the 1944 Chicago Convention, which asserts that every sovereign state has full sovereignty. The consequence of this principle of sovereignty is that no aircraft fly in or to or through the national airspace of a member state without obtaining permission in advance, no matter how high or low the aircraft is flying. In terms of state defense and security, air space has a closed nature because of air as a medium prone to violations (Wiradipraja, 2014).

Infringement of airspace can occur when an aircraft, both civil and military aircraft, enters the territory of another country without prior permission to the country that has sovereignty over the airspace before entering it. It means that a country's airspace is closed to another country. The use and control of the airspace is only a full and full right of the state (Rudy, 2002).

One case related to violations of the sovereign territory is the shooting of two military aircraft owned by India by Pakistan in Kashmir. There was a firing of two Indian fighter planes by Pakistan in the Kashmir region, part of Pakistan's sovereignty. One of the aircraft crashed in Pakistan-controlled Kashmir while another crashed in Indian-controlled Kashmir. In that incident, a pilot was arrested. One day after the incident, a Pakistani plane broke into Poonc and Nowhera, two locations in the de facto region of India. Pakistan launches a line of control in Kashmir. Pakistan stated that the attack targeted non-military targets and did not intend to worsen the tense situation (Impiani, 2019).

In the incident of the Indian military aircraft crash, India used a MiG-21 Bison military aircraft, which was included in an interceptor aircraft that was specifically designed to intercept and destroy the enemy. The Pakistani military spokesman confirmed that 
Pakistan had shot an Indian military plane and denied that in the shooting, Pakistan used an F-16 Jet to shoot down an Indian aircraft. Regarding the captured pilots, Pakistan returned the arrested-Indian pilots during the incident to coincide with the massive surrender of Islamabad called the "peace movement," which appears to reduce tensions significantly. Still, both sides remain on high alert (Kaura, 2020).

Both countries both claim that in the Line of Control (LoC), the de facto border between the two countries in the disputed Kashmir region, there has been relative tension in the last 24 hours (Arianta et al., 2020). But Indian security forces say they carry out a sizeable anti-militant operation on their side in the Kashmir region and have shot dead two militants (Hutapea, 2019).

A spokesman for the Indian defense forces claimed that on Tuesday night, Pakistan had fired using heavy weapons in 12 to 15 locations along the de facto border, which became the border of the two countries known as the Line of Control (LoC). In the incident, five Indian soldiers suffered minor injuries. To this, the United States Secretary of State, Mike Pompeo, spoke separately with foreign ministers of India and Pakistan. He urged the two countries to avoid further military activity after the airstrike (Pegahi, 2019).

Based on the chronology of the case, there has been a violation of international law in aircraft firing by Pakistan against Indian military aircraft. Article 1 of the 1944 Chicago Convention on International Civil Aviation recognizes that every sovereign state has complete sovereignty over the airspace above it (Martono \& Sudiro, 2016). The provisions in this convention are one of the main pillars governing air law (Rudy, 2002).

Pakistan, in this case as a country, under the responsibility of being in the air sovereignty. The determination of a no-fly zone in an area deemed prone to violations is the full responsibility of the sovereign state. It is because countries that are sovereign about their airspace know more about the security of their airspace. Pakistan, which in this case is a country whose air sovereignty has been violated by Indian military aircraft, should first confirm before firing on Indian military aircraft either by notification, returning the aircraft to its home country, or forcibly dropping (Ciptantri, 2018).

The state, in this case, as the subject of international law, is responsible when not carrying out its obligations, has committed negligence that is against the law (Sefriani, 2016). The state commits not to abuse its sovereignty; therefore, the government can be held accountable for acts of negligence that have been done (Adolf, 1996). Pakistan has neglected the authority of the airspace that is above its sovereign territory passed by Indian military aircraft that is not coordinating in advance with India related to the shootings it has done, and the no-fly zone has been established. 
The rule of international air law is one of the foundations for a country to secure its territorial sovereignty. Still, in its development, there are often violations of sovereignty territory, especially in airspace with various causes. One case related to violations of the sovereign territory is the shooting of two military aircraft owned by India by Pakistan in Kashmir.

The act of firing on two Indian military aircraft carried out by Pakistan constitutes the right of air control over military aircraft according to the Paris Convention of 1919 and the Chicago Convention of 1944. According to this convention, control rights over foreign military aircraft are strict and maximum. It does not contain exceptions to Article 32 of the Paris Convention and Article 3 (c) of the 1944 Chicago Convention. The right of maximum and strict control of the state over its airspace is only directed to military aircraft of other countries, where national security is the main reason. But still, the shooting action carried out by Pakistan against Indian military aircraft is an act of negligence on the airspace, which became its sovereignty, due to the lack of coordination related to the shootings carried out. Therefore, based on the discussion above, the authors formulate the problem: 1) What are the arrangements for military aircraft, especially Indian military aircraft, in the 1944 Chicago Convention on Military Aircraft Flights to Airspace in Other Countries? 2) What is the responsibility of the state of Pakistan for the firing of Indian military aircraft in violation of the sovereignty of Indian military aircraft? So the authors are interested in doing legal writing with the title "State Responsibility of Pakistan in Shooting Military Aircraft From the Perspective of International Air Law.

\section{Methodology}

The type of research used by the author in this study is the type of normative legal analysis. According to Soerjono Soekanto and Sri Mamudji, defining normative legal research is legal research through library materials and legislation documents (Ishaq, 2017). This type of research is a type of normative legal research approached by statutory and case. The data sources are divided into primary, secondary, and tertiary legal materials. It then interpreted, argued, and discussed descriptively.

\section{Results and Discussion}

\section{Military Aircraft Arrangements Specifically Indian Military Aircraft In the 1944 Chicago Convention Regarding Military Aircraft Flights to Airspace in Other Countries}

Military aircraft in international law are aircraft explicitly used for armed forces that do not have the right to fly over the sovereign territory of another country. In Article 3 of the 1944 Chicago Convention, military aircraft are categorized as state aircraft. State aircraft are aircraft used for military, police, and customs. Therefore, military aircraft are planes used by the state (Bourbonniere \& Haeck, 2000).

Besides, it is explained in Article 31 of the 1919 Paris Convention that each aircraft ordered by someone working in military service with specific goals is considered a 
military plane (Mangku, 2011). In international law, the rights and obligations of military aircraft are distinguished from public aviation. As regulated in article 32 of the 1919 Paris Convention, "no military aircraft of a contracting state shall fly over the terms of another contracting state nor land thereon without special authorization (permission)." The intention is that military aircraft (the state) do not have the right to fly over the territory of a member of the Paris Convention 1919 before obtaining permission in advance from the country concerned (Cooper, 1951).

Military aircraft in international law are classified based on the use of the plane, the classifications are as follows (Kurz \& Bartles, 2007; Guillaume, 2004; Leino et al., 1998):

\section{Bombers}

From its use, the role of the bomber is exact, namely dropping bombs on target areas. Bombers in the military world can be divided into two, namely strategic bombers with a very far-reaching range and tactical bombers whose firing range is shorter, usually used by ground forces.

2. Attack aircraft

Attack aircraft, or what is called international ground attack aircraft, is a type of military aircraft assigned to provide direct support to the movement of ground troops, both infantry and tanks, so that they can move quickly and safely. That is why the attack aircraft is always in front of the battle line to open the lane.

3. Fighter

As the name implies, fighter aircraft are assigned to conduct aerial battles, so they are required to move swiftly and perform sharp maneuvers. Therefore, this type of fighter aircraft is usually small and slim.

4. Interceptor aircraft

The interceptor aircraft is specifically designed to intercept and destroy enemy aircraft, especially bombers that usually use high speeds. Two types of interceptors are distinguished based on their respective performance. The first type of point interceptor defense aircraft is designed to take off and climb as fast as possible to attack the heights of other aircraft. And the second type of area defense interceptor is designed to protect a wider area from enemy attacks.

5. Spy planes

This type of aircraft is seen from its name, and its function is used to carry out intelligence tasks or spy on an area, including conducting surveillance and strategic surveillance. These reconnaissance aircraft are usually flown first before carrying out military operations. This aircraft has several types, the first type of reconnaissance aircraft used to collect strategic reconnaissance data. This aircraft can infiltrate and fly higher so as not to be reached by enemy defense missiles.

6. Anti-Guerrilla Attack Aircraft

This type of aircraft is a land attack aircraft devoted to assisting ground forces in dealing with guerrilla forces. The aircraft used are light aircraft capable of flying along with the land, weapons, and technology that are less complicated than other 
attack aircraft. Examples of these aircraft are OV-10 Bronco (United States), Pucara (Argentina), Pilatus (Switzerland), EMB-314 Super Tucano (Brazil), Super Skymaster, Piper PZL Dragonflies (Poland), BN-2A Islander.

7. Train Fighter

Trained combat aircraft in the military world is not used for attacks but are used to train prospective pilots. For most countries, fighter planes are considered to be relatively expensive, so training fighter planes are often used for anti-guerrilla attack aircraft. It is due to maintain pilot skills and save training and operational costs. Some of the combat trainer planes, for example, Guizhou JL-9 (China), Aero L-39 Albatros (Czech Republic), Kawasaki T-4 (Japan), Yakovlev Yak-130 (Russia), and Goshawk (America).

Based on the previous, the Mikoyan-Gurevich or also known as the MiG-21 Bison owned by India, belongs to an interceptor aircraft, which in this case is specifically designed to intercept and destroy enemy aircraft, especially bombers that usually use high speed. Thus, the MiG-21 bison aircraft owned by India in international air law is classified as a military aircraft (state), which is used for state purposes (Tufail, 2019). This provision is stipulated in article 3 of the 1944 Chicago Convention, which states that military aircraft are categorized as state aircraft used for military, police, and customs for the needs of the country.

Besides, if reviewed based on article 32 of the Paris 1919 Convention, the MiG-21 Bison aircraft owned by India does not have the right to fly over the territory of a member of the Paris 1919 convention before obtaining prior permission from the country concerned. Thus, the flight carried out by India over Pakistan's sovereign territory constitutes a violation of air sovereignty territory in international law, which caused the crash of the aircraft to be shot.

\section{State Liability in International Law}

Liability law in international law is related to talking about its main characteristics, then the state as the main subject (Ramsey, 2009). It is reflected in the first article of the draft articles on responsibility in international law by The International Law Commission (ILC), which states that "every internationality is wrong the act of state entails the international responsibility of that state." The point is that any state action that is deemed to be internationally responsible for the obligations of the country concerned (Thontowi, 2006).

The Draft Articles on Responsibility of States for International Wrongful Acts circulated by the UN General Assembly through Resolution A / RES / 56/83 talks about the responsibility of the state because of acts blamed under international law. In essence, state responsibility arises when the following actions occur:

1. Violation of subjective rights by other countries; 
2. Violations of international legal norms, which are jus cogens (basic principles recognized by the international community and the international community as norms that must not be violated);

3. And actions that qualify as a transnational crime. The actions referred to here are actions that must be measured whether they contain elements of necessity. The state must be responsible for these actions. This provision is held in international treaties and international customary law.

The state as a subject in international law can be held liable if its actions are detrimental to other countries and fulfill the characteristics of accountability. The types of state accountability are as follows (Adolf, 1996):

1. Delictual liability

It arises when a country commits an act of terror against foreigners in its territory.

2. Contractual liability

This responsibility occurs when a country violates an agreement made with another country.

3. Responsibility for concessions.

This responsibility is mentioned in the inter-state concession agreement, and it is also known as Clasula Alvo. It stipulates that the concessionaire relinquishes the protection of his government in disputes arising from the deal. The argument must be submitted to the national court of the concession-giving country and subject to the country's national law.

4. Responsibility for expropriation. Namely in the form of revocation of private property accompanied by the provision of compensation in the public interest.

5. Responsibility for state debt. This responsibility arises when a country does not pay off foreign debts, in the sense of not fulfilling contractual obligations or debt agreements.

The state which is involved in international law is motivated by the thought that no country in the world can enjoy its rights without respecting the rights of other countries. Any party that opposes another country is obliged to take responsibility for everything related to international law. It is a challenge in the legal system globally, where fighting the binding ties of the law will lead to accountability for violators (Sefriani, 2016).

International law. State accountability in international law has two understandings, which are supported. First, that is accountability for state actions that violate international obligations. The second, namely the responsibility, is taken by the state for opposing foreigners (Thontowi, 2006).

As stated earlier, state responsibility arises as a result of the principle of equality and state sovereignty contained in international law. This principle then gives authority to a country that has violated its right to demand reparations. In national law, it has been distinguished between criminal and civil liability and international law, several 
provisions are similar to national law, but this is not prominent. It is because international law regarding accountability has not developed so rapidly (Thontowi, 2006).

In essence, accountability arises due to violations of international law. A country is said to be responsible if the government violates international treaties, violates the sovereignty of another country, even treats foreign nationals arbitrarily. For this reason, state liability varies depending on the obligations it carries or the number of losses incurred (Thontowi, 2006).

International law experts recognize that state responsibility is a fundamental principle in international law. However, on the other hand, they also acknowledge that state responsibility law is still at the stage of discovering its concept and is still developing. In general, international law only explains the characteristics of the emergence of state responsibility as follows (Sefriani, 2016):

1. The existence of an international legal obligation that applies between two specific countries;

2. The existence of an omission that violates the obligations of international law, which bear the responsibility of the state;

3. The damage or loss resulted from unlawful or negligent actions.

Although it has never been universally agreed upon, the above characteristics are widely followed in classical international law. Thus state responsibility can only be prosecuted in international relations when there is a country that is harmed by another country due to violations of the obligations of negligence that arise from international treaties, international customs, and court decisions (Sefriani, 2016).

\section{Pakistan's State Responsibility for the Shooting of Indian Military Aircraft}

Violation of the sovereignty of a country's airspace is carried out by various types of aircraft, both civil aircraft and military (state) aircraft. In the case of violations of the country's airspace sovereignty carried out by military aircraft, recently carried out by Indian military aircraft, the type of interceptor MiG-21 Bison, ended with the crash shot. The shooting incidents of Indian military aircraft belonging to the MiG-21 Bison interceptor in Pakistani airspace, based on the chronology of the case described above, can be said that the shooting carried out by Pakistan over the territory under its jurisdiction constitutes an act of abuse of power in international law.

Pakistan, whose airspace is violated by Indian military aircraft, is obliged to warn of violations of the plane, either by ordering the aircraft to return or leave the airspace or order to land. In the event of a territorial breach, the country can carry out official channel broadcasts so that the aircraft registering country, in this case, the Indian state, expresses its apology. Whenever it incurs a loss, it can demand compensation for the losses suffered. However, when the country uses weapons and firing it without warning to return to their proper path or land or return to their country, it is apparent 
in international law that the country's actions violate international law (CNN Indonesia, 2019).

The responsibility that is borne by Pakistan is a responsibility that is taken because it violates a provision in international law, which in this case violates a principle in international law recognized by international organizations and the international community as a general principle called jus cogens. Also, Pakistan is known to have been a member of the 1944 Chicago Convention and has ratified it in 1947. If Pakistan violates the provisions of the 1944 Chicago Convention, then Pakistan, as a country, must provide accountability when causing harm to other countries.

According to the legal doctrine on self-defense, the use of weapons as a medium to force aircraft that violates the sovereignty of a country's airspace is excessive and unbalanced with the threats they face. Especially in international law, the country's actions can be an abuse of power (Mangku \& Radiasta, 2019). The shooting of military aircraft is indeed not regulated in detail in international law. But still, if we look at the implicit or explicit intent of the context of the rules in Article 44 letter (a) the 1944 Chicago Convention, the use of weapons as a medium for forcing aircraft violating sovereign territory is not in line with the principle of safety first in international air law. India can hold Pakistan accountable for firing and arresting pilots in the form of compensation or restitution for the destroyed-aircraft. Also, request in the form of a letter that firing a military aircraft is an act of armed aggression as a form of abuse of power.

The responsibility of the state of Pakistan in the firing of Indian military aircraft is the responsibility arising from acts of criminal (delictual liability). It can be seen from the arbitrary actions taken by Pakistan in the form of aircraft firing and the capture of pilots, which in international law are qualified as acts of abuse of power in their sovereignty (Adolf, 1996).

According to the author, the responsibility arising from the shooting action carried out by Pakistan is stopping the act and remedial action in the form of restitution. Pakistan, as a responsible country, must cease its activities and promise not to repeat them (Wiradipraja, 2014). Besides, there is accountability in the form of remedial actions; this is stipulated in Article 31 of the ILC draft on state accountability. The responsible state must take full corrective actions for violations of the impaired rights, both in material and moral form arising from the international error. For this reason, Pakistan, in this case, must provide corrective action in the form of restitution, in the form of repairs in the way of goods, namely repairing the original aircraft that had been shot, namely the MiG-21 Bison aircraft, and providing protection against the pilots captured (Shaw QC, 2013).

Based on the previous explanation, it can be said that the shooting of military aircraft is also prohibited in international law. Provided that the shooting action carried out is intended to force the military aircraft that commits the violation to return to their 
home country. This provision is as regulated in Article 44 letter (a) of the 1944 Chicago Convention that the use of weapons as a medium for forcing aircraft violating sovereign territory is not in line with the principle of safety first in international air law. Besides, before the shooting, the country that carried out the shooting did not confirm in advance that the military aircraft violated the country's air sovereignty. That is why the shooting is categorized as an abuse of power.

\section{Conclusion}

Based on the discussion of the overall results of the research conducted by the author, it can be concluded that the arrangement of the Indian military aircraft MiG-21 Bison interceptor in the Paris Convention of 1919 is categorized as a state aircraft. In this case, do not have the right to fly over the sovereignty of another country before obtaining prior permission from the government concerned as regulated in Article 32 of the 1919 Paris Convention. Therefore, flights carried out by India over Pakistan's sovereign territory constitute violations of air sovereignty territory under international law, led to the crash of the aircraft by Pakistan.

The form of responsibility that must be carried out by Pakistan is the termination of acts and remedial actions in the form of restitution, namely repairing the original Indian military aircraft that he had shot down and providing protection for the captured pilots. Additionally, Pakistan must apologize in the form of a letter to India that the shooting was an act of armed aggression as a form of abuse of power.

\section{References}

Adolf, H. (1996). Aspek-aspek dalam hukum internasional. Jakarta: PT Raja Grafindo Persada.

Arianta, K., Mangku, D. G. S., \& Yuliartini, N. P. R. (2020). Perlindungan Hukum Bagi Kaum Etnis Rohingya Dalam Perspektif Hak Asasi Manusia Internasional. Jurnal Komunitas Yusisia, 3(2), 93-111. http://dx.doi.org/10.23887/jatayu.v3i2.28849

Bourbonniere, M., \& Haeck, L. (2000). Military aircraft and international law: Chicago opus 3.Journal of Air Law \& Commerce, 66(3), 885. Retrieved from https://scholar.smu.edu/jalc/vol66/iss3/2/

Ciptantri, S. B., Mangku, D. G. S., Yuliartini, N. P. R. (2018). Pertanggungjawaban egara Uni Soviet atas penembakan pesawat Korea Air Lines ditinjau dari perspektif hukum udara internasional. Jurnal Komunitas Yustisia, 1(2). http://dx.doi.org/10.23887/jatayu.v1i2.28732

Cooper, J. C. (1951). United States participation in drafting Paris Convention 1919. Journal of Air Law \& Commerce, 18(3), 266. https://scholar.smu.edu/jalc/vol18/iss3/2

Guillaume, G. (2004). Terrorism and international law. International \& Comparative Law Quarterly, 53(3), 537-548. https://doi.org/10.1093/iclq/53.3.537 
Hutapea, R. U. (2019). Pakistan tembak jatuh 2 pesawat tempur India di Kashmir. Retrieved in Januari 1, 2020, from https://news.detik.com/internasional/d4446513/pakistan-tembak-jatuh-2-pesawat-tempur-india-di-kashmir

Impiani. (2019). Escalation of military conflict between India and Pakistan in the postLahore Declaration (1999-2019): Security dilemma perspective. Global:Jurnal Politik Internasional, 21(2). https://doi.org/10.7454/global.v21i2.403

Ishaq. (2017). Metode Penelitian Hukum dan Penulisan Skripsi, Tesis, serta Disertasi. Jakarta: Alfa Beta.

Kaura, V. (2020). India's Pakistan policy: from 2016 surgical strike to 2019 Balakot 'airstrike.' The Round Table: The Commonwealth Journal of International Affairs 109(3). https://doi.org/10.1080/00358533.2020.1760499

Koh, H. H. (1998). Is international law really state law? Harvard Law Review, 111(7) 1824-1861. DOI:10.2307/1342484

Kurz, R. W., \& Bartles, C. K. (2007). Chechen suicide bombers. Journal of Slavic Military Studies, 20(4), 529-547. https://doi.org/10.1080/13518040701703070

Leino, T. K., Leppäluoto, J., Ruokonen, A., \& Kuronen, P. (1998). Pro-opiomelanocortin activation and simulated interceptor combat flight. Aviation, space, and environmental medicine,69(5), 486-490. Retrieved from https://europepmc.org/article/med/9591619

Mangku, D. G. S. (2011). Peluang dan tantangan ASEAN dalam penyelesaian sengketa Kuil Preah Vihear di perbatasan Kamboja dan Thailand. Pandecta: Research Law Journal, 6(2), 106-116. https://doi.org/10.15294/pandecta.v6i2.2329

Mangku, D. G. S., \& Radiasta, I. K. (2019). Tanggung jawab negara terhadap penembakan pesawat MH17 berdasarkan hukum internasional. Pandecta: Research Law Journal, 14(1), 25-33. https://doi.org/10.15294/pandecta.v14i1.1898

Martono, H. K., \& Sudiro. (2016). Hukum udara nasional dan internasional publik. Jakarta: PT Raja Grafindo Persada.

Pegahi, T. N. (2019). From Kargil to Pulwama: How nuclear crises have changed over 20 years. The Washington Quarterly, 42(2). https://doi.org/10.1080/0163660X.2019.1626690

Ramsey, M. D. (2009). International law limits on investor liability in human rights litigation. Harvard International Law Journal,50, 271. Retrieved from https://bit.ly/310BMUr

Rudy, M. T. (2002). Hukum internasional 2. Jakarta: Refika Aditama.

Sefriani. (2016). Hukum internasional suatu pengantar edisi kedua. Jakarta: Rajawali Press.

Shaw QC, M. N. (2013). Hukum internasional (International law). Jakarta: Nusa Media.

Saul, B. (2013). China, natural resources, sovereignty and international law. Asian Studies Review, 37(2), 196-214. https://doi.org/10.1080/10357823.2013.769497

Thontowi, J. (2006). Hukum internasional kontemporer. Jakarta: PT Refika Aditama. 
Tufail, A. C. K. (2019). Pulwama-from bluster to a whimper. Defence Journal, 22(12), 32.

Williams, A. J. (2010). A crisis in aerial sovereignty? Considering the implications of recent military violations of national airspace. Area,42(1), 5159. https://doi.org/10.1111/j.1475-4762.2009.00896.x

Wiradipraja, S. (2014). Pengantar hukum udara dan ruang angkasa. Bandung: Alumni. 